УДК 631.95:631, DOI 10.31210/visnyk2018.02.17

(C) 2018

Ласло О. О., кандидат сільськогосподарських наук, Диченко О. Ю., кандидат сільськогосподарських наук, Нагорна С. В., кандидат сільськогосподарських наук

Полтавська державна аграрна академія

\title{
МЕТОДОЛОГІЧНІ ОСНОВИ АГРОЕКОЛОГІЧНОЇ ОПТИМІЗАЦЇ̈ ТА ВИЗНАЧЕННЯ ІНТЕГРАЛЬНОГО ПОКАЗНИКА ЕКОЛОГІЧНОГО СТАНУ ПОЛТАВСЬКОЇ ОБЛАСТІ У СИСТЕМІ СТІЙКОГО РОЗВИТКУ СІЛЬСЬКИХ ТЕРИТОРІЙ
}

\section{Рецензент - доктор сільськогосподарських наук, професор П. В. Писаренко}

У статті розглянуто доиільність та необхідність агроекологічної оптимізації та визначення інтегрального показника екологічного стану Полтавської області. Наведені результати досліджень доводять, щзо методологія визначення інтегрального показника стану Полтавщини у системі стійкого розвитку селітебних територій дає можливість оптимізувати територію області для виробництва органічної продукиії. Для досягнення мети використано методики науковців, щзо дозволяють провести ранжування $i$ встановити критерії антропогенного впливу на екологічний стан довкілля.

Ключові слова: інтегральні показники, антропогенний вплив, селітебні території, екологічний стан земельних територій, екологічна стабільність.

Постановка проблеми. Парадигма стратегії раціонального природокористування передбачає формування адекватного понятійного апарату, удосконалення еколого-нормативно-правової бази, узгодження розвитку аграрного природноресурсного потенціалу 3 пріоритетами соціально-економічної політики $[1,4]$.

Аналіз останніх досліджень i публікацій, у яких започатковано розв'язання проблеми. Забезпеченню збалансованого розвитку агровиробництва має передувати впровадження екологізації виробництва продуктів харчування, проведення інвентаризації та екологічної паспортизації екологічно небезпечних (тобто екологічно нестабільних) територій з умовою подальшої координації екологічних заходів у досліджуваному регіоні.

Методологічною основою екологічної стратегії має стати концепція сталого розвитку продуктивних сил продовольчого підкомплексу. До еколого-економічних пропорцій між місткістю аграрного природно-ресурсного потенціалу та рівнем соціально-економічного розвитку регіонів належать наступні пропорції: між сировинним потенціалом та виробничими можливостями щодо його використання, потенційними ресурс- ними можливостями та гранично допустимим виробничо-господарським навантаженням, експлуатацією та розширеним відтворенням аграрних ресурсів довкілля продовольчого призначення [2].

В. М. Трегобчук вказує, що сталий соціальноекономічний розвиток економіки держави (зокрема у нашому випадку продовольчого підкомплексу) означає, що його функціонування забезпечує задоволення матеріальних, культурних та духовних потреб людини, тобто економічне зростання спрямоване на досягнення комплексного соціально-економічно-екологічного ефекту [10]. Основними екологічно-деструктивними чинниками впливу виробництва продуктів харчування та продовольчої сировини на якісний стан ресурсів довкілля є велика масштабність і розселеність, високий рівень порушення екологічно недопустимого структурного співвідношення земельного фонду, нераціональна структуру посівів, недотримання технології виробництва продовольства [9].

Виробництво продуктів харчування та продовольчої сировини пов'язане 3 ефективним функціонуванням агропромислового комплексу. Інтенсифікація виробництва продовольства за умов еколого-економічної кризи не повинна руйнувати екологічну стабільність довкілля.

Вартісний вираз природного капіталу враховує крім господарського значення також ресурсну та екологічну цінність. Природні екосистеми $€$ значно складнішими у порівнянні 3 традиційними факторами виробництва продовольства (засоби виробництва, фінансовий капітал, праця). Основними причинами низької віддачі земельно-ресурсного потенціалу у продовольчому виразі є відсутність реального власника та мотивації, недосконала цінова та інвестиційнокредитна політика [5, 8]. Раціональність природокористування характеризується показниками структури використання території, якістю еколо- 


\section{СІЛЬСЬКЕ ГОСПОДАРСТВО. ЕКОЛОГІЯ}

гічного потенціалу землі.

На думку вчених, для оцінки впливу якісного складу угідь на екологічну стабільність території необхідно провести розрахунок коефіцієнтів екологічної стабільності території.

Метою досліджень $є$ аналіз методологічної бази 3 інтегрування, ранжування та нормування екологічних показників, що характеризують стан селітебних територій Полтавської області.

Результати досліджень. Рівень інтенсивного використання земельних ресурсів $є$ показником аналогічним фондооснащеності. Результативність господарювання на землі характеризується розміром валової продукції та урожайністю. Коефіцієнт інтенсивності використання землі розраховується відношенням площі орних земель та інших видів угідь до загальної площі сільськогосподарських угідь.

У таблиці 1 подано нормативні величини коефіцієнтів екологічної стабільності для різних видів земельних угідь за Волковим С. М. [2]

Аналіз показників екологічної стабільності показав, що величина коефіцієнту екологічної стабільності території Полтавської області знаходиться у межах 0,34-0,50, тому за шкалою градації (таблиця 2) має нестійко стабільну екологічну стабільність території (розрахунки проведені автором на основі статистичних даних по Полтавській області та Агроекологічного атласу Полтавщини [3]). Доведено, що при підвищенні сільськогосподарської освоєності та розораності земельних угідь істотно знижується екологічна стійкість ландшафтів. Загальний коефіцієнт еко-

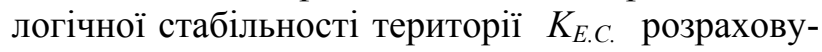
ється за формулою:

$$
K_{E . C .}=\left(\sum K_{l i} \cdot P_{i} / \sum P_{i}\right) \cdot K_{P},
$$

де $K_{l i}$ - коефіцієнт екологічної стабільності угідь $i$-го виду;

$P_{i}$ - площа угідь $i$-го виду;

$K_{p}$ - коефіцієнт морфологічної стабільності рельєфу $\left(K_{p}=1\right.$ для стабільних і $K_{p}=0,7$ для нестабільних територій).

Проведені розрахунки показали, що коефіцієнт екологічної стабільності території Полтавської області становить 0,38 , тоді як середній коефіцієнт екологічної стабільності території України складає 0,4 , що свідчить про екологічну нестабільність території нашої держави. Як відомо, екологічно стійкі угіддя, зокрема ліси, позитивно впливають на навколишню територію. Вага впливу угідь на навколишні землі визначається за формулою:

$$
Д=100 \ln P / \ln \left(10 / K_{2}\right) \text {, }
$$

де $P$ - площа угідь;

$K_{2}$ - коефіцієнт екологічного впливу території на навколишні землі.

Величина прибутку з 1 га земельної площі характеризує економічну ефективність використання землі. Значення земельних ресурсів як джерела продовольства дедалі зростає.

\section{1. Нормативна величина коефіцієнтів екологічної стабільності [джерело даних 2]}

\begin{tabular}{|l|c|c|}
\hline \multicolumn{1}{|c|}{ Види земельних угідь } & $\begin{array}{c}\text { Коефіцієнт екологічної } \\
\text { стабільності території }\left(\mathrm{K}_{1}\right)\end{array}$ & $\begin{array}{c}\text { Коефіцієнт екологічного } \\
\text { впливу угіддя на навколишні } \\
\text { землі }\left(\mathrm{K}_{2}\right)\end{array}$ \\
\hline 3абудована територія і дороги & 0,00 & 1,27 \\
\hline Рілля & 0,14 & 0,83 \\
\hline Виноградники & 0,29 & 1,47 \\
\hline Лісосмуги & 0,38 & 2,29 \\
\hline Фруктові сади, чагарники & 0,43 & 1,47 \\
\hline Городи & 0,50 & 1,59 \\
\hline Сіножаті & 0,62 & 1,71 \\
\hline Пасовища & 0,68 & 1,71 \\
\hline Ставки і болота природного походження & 0,79 & 2,93 \\
\hline Ліси природного походження & 1,00 & 2,29 \\
\hline
\end{tabular}

\section{2. Шкала градації величини коефіцієнту екологічної стабільності земельної території}

[ожерело даних 2]

\begin{tabular}{|l|c|}
\hline \multicolumn{1}{|c|}{ Екологічна стабільність території } & $\begin{array}{c}\text { Величина коефіцієнту екологічної стабільності земельної } \\
\text { території }\end{array}$ \\
\hline Нестабільна & $<0,3$ \\
\hline Нестійко стабільна & $0,34-0,50$ \\
\hline Середньо стабільна & $0,51-0,66$ \\
\hline Стабільна & $>0,67$ \\
\hline
\end{tabular}




\section{СІЛЬСЬКЕ ГОСПОДАРСТВО. ЕКОЛОГІЯ}

Далеко не завжди сприятливі погодні умови та подорожчання освоєння нових земель забезпечують достатньою мірою відтворення родючості грунтів, збереження землі як природного ресурсу.

3більшення сільськогосподарського освоєння земельних ресурсів, що супроводжується зростанням розораності угідь, свідчить про підвищення антропогенного навантаження на одиницю земельної площі. Безумовно, це не може не вплинути на екологічний стан навколишнього середовища. Критерієм екологічної ефективності землекористування $\epsilon$ відновлення природного стану грунтів, тобто темпи відтворення їх родючості.

Охорона навколишнього середовища, зростання природно-ресурсного потенціалу земельного регіону є похідними від екологізації землекористування [7].

Як зазначає Коренюк П. І., до екологічно небезпечних галузей, які мають глобальний характер, уже завтра можна буде віднести й аграрне виробництво, де вже сьогодні стають масштабними процеси деградації грунтового покриву, забруднення пестицидами, мінеральними добривами та іншими хімікатами навколишнього середовища, підвищення вмісту в продуктах харчування небезпечних і просто шкідливих речовин. Ці процеси мають бути призупинені. Основний спосіб виходу 3 цього становища - припинити нераціональне використання землі, зменшити ступінь розораності, вивести 3 інтенсивного землеробства схилові землі, що мають крутизну понад $7^{\circ}$, із розміщенням на них луків, пасовищ, а на надто крутих - лісопосадок тощо. Необхідно перейти до стратегії оптимізації використання і охорони земельних ресурсів на принципах адаптованості, тобто пристосування землекористувачів до прояву природних процесів, грунтово-кліматичних умов кожного регіону.

Поява негативних чинників аграрного походження, що впливають на екологічну безпеку, пояснюється недосконалим обгрунтуванням індустріалізації сільськогосподарського виробництва i його інтенсифікації. Поглиблюються ці процеси надмірним використанням мінеральних добрив і отрутохімікатів, концентрацією відходів великих промислових тваринницьких комплексів при відсутності в них очисних споруд тощо. Внаслідок цього посилюється забрудненість продуктів харчування шкідливими речовинами, погіршується природне середовище життя людини.

Для оцінки структурного впливу угідь на екологічну стабільність території проведено розрахунок коефіцієнтів екологічної стабільності зе- мельної території Полтавської області. Екологічна ситуація досліджуваного регіону за останні роки знаходиться у передкризовому (нестійко стабільному) стані. Проте у кількох районах області спостерігається тенденція до підвищення екологічної стабільності земельної території (Шишацький, Глобинський та Котелевський райони).

Поряд із позитивною тенденцією поліпшення екологічної стабільності земельних угідь, агроекологічна ситуація у цілому по Полтавській області залишається передкризовою.

На Полтавщині екологізація виробництва продуктів харчування та продовольчої сировини передбачає економічно та екологічно виправдану інтеграцію на європейський ринок.

Індикативні програми екологізації продовольчого комплексу враховують внутрішньогалузеві пріоритети, спеціалізацію, аграрний природноресурсний потенціал території, матеріальнотехнічну забезпеченість сільськогосподарських товаровиробників [6].

Вирішити всі проблеми екологічного, економічного та соціального характеру, що властиві продовольчому комплексу як Полтавщини, так $\mathrm{i}$ України, лише за допомогою ринкових важелів можливо. Розв'язання даного питання можливе при підтримці держави в реалізації екологічної концепції України та законодавчо-правовій базі.

Екологічна стабільність земельної території $\epsilon$ базовим показником для розробки коефіцієнту інтегрованого екологічного стану землекористування.

У сучасних умовах економіко-соціальні досягнення будь-якого регіону країни, зокрема і Полтавщини, не можна повноцінно оцінити без урахування антропогенного тиску на довкілля. Екологічний індекс має враховувати ступінь цілісності й ефективного функціонування екосистем, ступінь екологічного добробуту населення промислових регіонів, підтримку на державному рівні, роботу і підтримку спеціалізованих організацій і формувань різних рівнів. 3 метою екологічної стабілізації територій необхідно знизити антропогенний вплив на природні системи, що не перевищував би гранично допустимого рівня навантаження на ресурси навколишнього середовища. Потенціал стійкого екологічного розвитку держави чи окремих регіонів розраховують таким чином:

$$
\begin{aligned}
& K_{\Pi}=E P+\Pi Р \Pi, \\
& E P=\frac{T H}{\Pi C+Б \Pi}+\text { НПП } \\
& \text { де } K n-\text { інтегральний коефіцієнт; }
\end{aligned}
$$




\section{СІЛЬСЬКЕ ГОСПОДАРСТВО. ЕКОЛОГІЯ}

$T H$ - потенціал техногенного навантаження на довкілля, куди входять показники соціальноекономічної освоєння території та забруднення довкілля;

ПС - потенціал самоочищення природного середовища;

БП - біотичний потенціал довкілля;

НПП - потенціал несприятливих природноантропогенних процесів;

ПРП - природно-ресурсний потенціал теритоpiï; [1].

ЕР - потенціал екологічного ризику території

Як відмітив Коренюк П. І., розробка методології дослідження інтегрального показника екологічного стану земельної території вимагає формування спеціалізованого понятійно-категоріального апарату. Розробка понять і категорій сприяє поглибленому розумінню економікоекологічних відносин, розумінь законів та закономірностей, конкретизації наукових напрямів, систематизації економіко-екологічних проблем розроблення наукових концепцій екологічної стабілізації земельної території. Шляхом співставлення фактичної концентрації шкідливих речовин у ресурсах довкілля і ГДК можна отримати індекс ступеня перевищення концентрації шкідливих та небезпечних речовин.

Екологічну небезпеку характеризують такі фактори: сільськогосподарське освоєння теритоpiï, розораність і лісистість, частка земель із нахилом більше $2 \%$, густота гідрографічної мережі, частка екологічно стабільних видів угідь, цілісність населення, ступінь концентрації тваринництва, величина пестицидного та хімічного навантаження на агроландшафт.

Створення полезахисних лісових смуг $\epsilon$ невід'ємним елементом системи заходів 3 інтенсифікації виробництва продуктів харчування та продовольчої сировини. Чистий дохід від меліоративного впливу полезахисних лісосмуг розраховують так:

Чठ $=B n-3 m-3 o n$,

де, $B n$ - вартість приросту урожаю, грн;

$3 m$ - технологічні витрати, грн;

Зоп - амортизаційні підрахунки, грн.

У свою чергу, складові даної формули розраховуються таким чином:

$$
\begin{aligned}
& B n=Ц\left(У_{3} S-\text { Убл }\right) \text {, } \\
& 3 m=\left(\text { Сб } х \text { Убл. }+3 y m \times У_{3}\right) S-\text { Сбх Убл. } \\
& (S+1)=3 m \text { УзУУбл, } \\
& 3 o n=\varphi x \text { Krn, } \\
& \text { де, } Ц \text { - закупівельна ціна } 1 \text { ц к.о. грн; } \\
& \text { Iз - прибавка урожаю на } 1 \text { га захищеного по- }
\end{aligned}
$$

ля, ц.к.о.;

$S$ - площа виробничого ефекту, га;

Iбл - урожайність на відкритому полі, ц.к.о./га;

$3 y m$ - загальний норматив прямих витрат на 1 ц при прибавки урожаю, грн;

Сб - фактична собівартість 1 ц.к.о.;

1 - площа ріллі, яка відчужується при посадці 1 га полезахисних лісових смуг;

$\varphi-$ середні щорічні амортизаційні підрахунки у залежності від народного складу лісонасаджень;

Квл - капітальні витрати на створення 1 га смуг, грн.

Інтегрований екологічний стан території - це такий стан, який максимально враховує увесь комплекс якісного складу видового ресурсного потенціалу довкілля. Доцільно виділити показники, які негативно або позитивно впливають на екологічний стан довкілля (рис. 1).

Один із фундаторів екологічної економіки лауреат Нобелівської премії "Right Livelihood Award" Герман Дейлі стверджує, що створена людиною економіка «вбудована» в екологічну глобальну систему. Якісні показники довкілля визначаються якістю атмосферного повітря, якістю земельних угідь сільськогосподарського призначення, якістю поверхневих вод та якістю біотичних ресурсів [8].

Природокористування в агропродовольчому комплексі $\epsilon$ досить специфічним. Регулювання стану аграрного природно-ресурсного потенціалу доцільно здійснювати на основі пріоритетного розвитку екологічно врівноважених технологій виробництва продуктів харчування та продовольчої сировини [8].

Отже, інтегрований коефіцієнт екологічного стану земельної території доцільно розраховувати таким чином:

Ki.e.c. $=$ Ке.с. $x$ Косв. $x$ ' Крз. х Кг.м. х Іщ.н. $x$ Ке.ш.о. х Пн х Хн,

Де Ке.с. - коефіцієнт екологічної стабільності території;

Косв. - коефіцієнт сільськогосподарської освоєності території;

Крз. - коефіцієнт розораності території;

Кг.м. - коефіцієнт густоти гідрографічної мережі, км/км ${ }^{2}$;

Іщ.н. - індекс щільності населення, чол./км²

Ке.ш.о. - коефіцієнт розміщення екологічно шкідливих об'єктів;

Пн., Хн. - пестицидне та хімічне навантаження, кг/га д.р. на рік. 


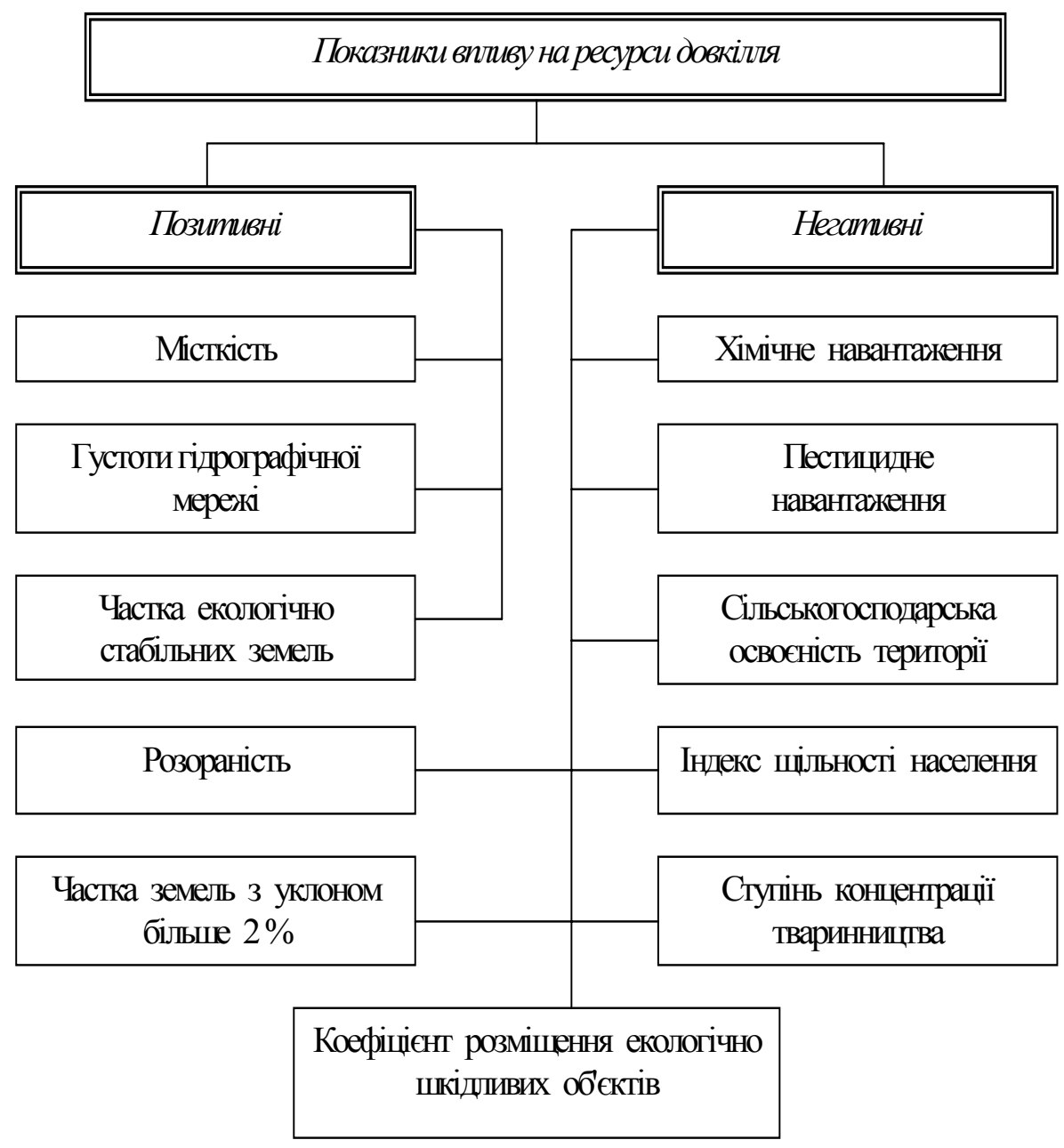

Рис. 1. Показники антропогенного впливу на екологічний стан довкілля [джерело даних 7]

\section{3. Нормативна шкала складових елементів визначення інтегрального коефіцієнта} екологічного стану земельної території [джерело даних 7]

\begin{tabular}{|c|c|}
\hline Відсотки & Величина коефіцієнту \\
\hline \multicolumn{2}{|c|}{ Коефіцієнт екологічної стабільності території } \\
\hline $1,0-0,66$ & Екологічно стабільна територія \\
\hline $0,65-0,50$ & Середньо стабільна територія \\
\hline $0,49-0,33$ & Екологічно мало стабільна територія \\
\hline$<0,33$ & Екологічно нестабільна територія \\
\hline \multicolumn{2}{|c|}{ Коефіцієнт сільськогосподарської освоєння території } \\
\hline$<60$ & 1,0 \\
\hline $60-70$ & 0,9 \\
\hline $71-80$ & 0,7 \\
\hline $81-90$ & 0,5 \\
\hline$>90$ & 0,3 \\
\hline \multicolumn{2}{|c|}{ Коефіцієнт розораності території } \\
\hline$<45$ & 1,0 \\
\hline $45-55$ & 0,9 \\
\hline $56-65$ & 0,8 \\
\hline $66-75$ & 0,7 \\
\hline$>75$ & 0,5 \\
\hline
\end{tabular}


СІЛЬСЬКЕ ГОСПОДАРСТВО. ЕКОЛОГІЯ

Продовження табличі 3

\begin{tabular}{|c|c|}
\hline Відсотки & \multicolumn{1}{|c|}{ Величина коефіцієнту } \\
\hline \multicolumn{2}{|c|}{ Коефіцієнт густоти гідрографічної мережі, км/км ${ }^{2}$} \\
\hline$<0,2$ & 1,0 \\
\hline $0,3-0,59$ & 0,8 \\
\hline $0,6-0,8$ & 0,6 \\
\hline $0,81-0,9$ & 0,4 \\
\hline$>0,9$ & 0,2 \\
\hline \multicolumn{1}{|c|}{ Пестицидне навантаження, кг/га д.р. на рік } \\
\hline $0,5-1,5$ & 1,0 \\
\hline $1,51-3,0$ & 0,8 \\
\hline $3,1-5,0$ & 0,6 \\
\hline$>5,0$ & 0,4 \\
\hline \multicolumn{1}{|c|}{ Хімічне навантаження, кг/га д.р. на рік } \\
\hline 100,0 & 0,2 \\
\hline $100-200,0$ & 1,0 \\
\hline $201,0-300,0$ & 0,8 \\
\hline $301,0-400,0$ & 0,6 \\
\hline$<400,0$ & 0,4 \\
\hline
\end{tabular}

4. Градаційна шкала інтегрального коефіцієнта екологічного стану земельної території [джерело даних 7]

\begin{tabular}{|c|c|}
\hline Величина коефіцієнта & Екологічна безпечність \\
\hline$<0,33$ & Екологічно кризовий \\
\hline $0,34-0,66$ & Екологічно передкризовий \\
\hline$>0,66$ & Екологічно помірно безпечний \\
\hline близько 1 & Екологічно безпечний \\
\hline
\end{tabular}

Відповідно до вищевказаного розрахунку інтегрального коефіцієнту екологічного стану земельної території, П. І. Коренюком запропонована відповідна нормативна шкала та шкала градації величини даного коефіцієнта (таблиці 3 та 4).

Отже, інтегральний індекс екологічного стану території є відносним показником, що характеризує комплексний стан земельної території регіону, країни тощо.

Проведені розрахунки по Полтавській області показали:

- коефіцієнт сільськогосподарської освоєння території-0,3.

- коефіцієнт розораності території - 0,5,

- коефіцієнт густоти гідрографічної мережі,

\section{БІБЛІОГРАФІЯ}

1. Барановський В. А. Стратегія екологічно сталого розвитку України / В. А. Барановський // Розбудова держави. - 1998. - № 9-10. - С. 18-22.

2. Волков С. М. Основы землевладения и землепользования / Волков С. М., Хлистун В. М., Улюкаєв В. Х. - М. : Наука, 1990. - 143 с.

3. Голик Ю. С. Агроэкологический атлас Полтавщины / Юрий Степанович Голик, 2009. - 70 с.

4. Голуб О. А. Стратегія раціонального лісоко- км/км² $-0,6$.

- пестицидне навантаження, кг/га д.р. на рік 0,6 ,

- хімічне навантаження, кг/га д.р. на рік - 0,6.

Висновок. Коефіцієнт екологічної стабільності території Полтавщини характеризується як екологічно малостабільна територія. Такий показник $є$ наслідком надмірного сільськогосподарського освоєння території та значного рівня розораності угідь.

За шкалою інтегрального коефіцієнта екологічного стану земельної території Полтавської області, величина якого складає 0,38 , характеризує iii стан $з$ точки зору екологічної безпеки як екологічно передкризовий.

ристування як складова загальної екологічної політики / О. А. Голуб, Р. Б. Бабич // Вісник Сумського державного університету: Спеціальний випуск "Екологічні проблеми виробництва та споживання екологічно чистої продукції”. Суми, 2001. - С. 130-133.

5. Касьяненько В. Ф. Екологічні аспекти сільськогосподарського землекористування / Касьяненько В. Ф. // Вісник Сумського державного 


\section{СІЛЬСЬКЕ ГОСПОДАРСТВО. ЕКОЛОГІЯ}

аграрного університету: Спеціальний випуск: "Екологічні проблеми виробництва та споживання екологічно чистої продукції”. - Суми, 2001. - C. 427-429.

6. Коренюк П. І. Менеджмент навколишнього природного середовища. / Коренюк П. І. - Дніпропетровськ: НГАУ, 2001. - 224 с.

7. Коренюк П. І. Методологічні засади визначення інтегрального показника екологічного стану земельної території / П. І. Коренюк // Екологія і природокористування. - 2003, Випуск 6. C. 85-91.

8. Несвєтов О. О. Біологічні ресурси - природний капітал / Несвєтов О. О. // Вісник Сумського державного аграрного університету: Спеціа-

\section{ANNOTATION}

Laslo O. O., Dychenko O. Yu., Nagorna S.V. Methodological bases of agroecological optimization and determination of the integrated indicator of the ecological state of Poltava region in the system of sustainable development of agricultural territories.

The article considers the expediency and necessity of agroecological optimization and determination of the integral index of the ecological state of Poltava region. The presented results of the research prove that the methodology for determining the in- льний випуск "Екологічні проблеми виробництва та споживання екологічно чистої продукції”. Суми, 2001. - С. 356-359.

9. Попова О. Л. Еколого-економічні проблеми сталого природокористування в аграрній сфері / Попова О. Л. // Економіка АПК. - 2000, № 11. C. 57-63.

10. Трегобчук В. М. Еколого-економічні проблеми переведення АПК на модель сталого розвитку / Трегобчук В. М. // Вісник Сумського державного аграрного університету: Спеціальний випуск: “Екологічні проблеми виробництва та споживання екологічно чистої продукції”. Суми, 2001. - С. 30-33.

tegral index of the condition of Poltava region in the system of sustainable development of residential territories gives an opportunity to optimize the territory of the region for the production of organic products. To achieve the goal, scientists' methods are used to make a ranking and establish criteria for anthropogenic impact on the environmental state of the environment.

Key words: integral indicators, anthropogenic influence, residential areas, ecological status of land territories, ecological stability. 